\title{
Ricketts' Cephalometric Analysis for Saudi Population
}

\author{
Ayesha Siddika1®, Shaifulizn Ab. Rahman²®, Mohammad Khursheed Alam ${ }^{\circledR}$
}

${ }^{1}$ School of Dental Science, Universiti Sains Malaysia, Kota Bharu, Malaysia.

${ }^{2}$ Oral and Maxillofacial Surgery Department, School of Dental Science, Universiti Sains Malaysia, Kota Bharu, Malaysia.

${ }^{3}$ Orthodontic Division, Preventive Dentistry Department, College of Dentistry, Jouf University, Sakaka, Saudi Arabia.

Author to whom correspondence should be addressed: Dr. Mohammad Khursheed Alam, Associate Professor, Orthodontic Division, HOD, Preventive Dentistry Department, College of Dentistry, Jouf University, Sakaka, Al Jouf, Saudi Arabia. Phone: +966 535602339. E-mail: dralam@gmail.com.

Academic Editors: Alessandro Leite Cavalcanti and Wilton Wilney Nascimento Padilha

Received: 31 October 2019 / Accepted: 14 March 2020 / Published: 01 April 2020

How to cite this article: Siddika A, Rahman SA, Alam MK. Ricketts' cephalometric analysis for Saudi population. Pesqui Bras Odontopediatria Clín Integr. 2020; 20:e5364. https://doi.org/10.1590/pboci.2020.059

\begin{abstract}
Objective: To evaluate the cephalometric norm for Saudi sample by Ricketts analysis (RA). Material and Methods: In this cross-sectional study, cephalometric radiographs were taken for 500 samples. The subjects included 250 males and 250 females. The ages of the subjects ranged from 18-30years. The criteria of selection were based on Class I incisor relationship, no skeletal abnormality and no previous orthodontic treatment. Lateral cephalometric radiographs were taken, traced and digitized by SPSS software, according to RA. An independent t-test was used to test the level of significance between genders. Results: Significant disparities found between Saudi males and females in dental and soft tissue measurements. The result showed that the distal position of the maxillary first molar to pterygoid vertical plane (U6 to Ptv) measurement was highly significantly greater $(\mathrm{p}<0.001)$ in Saudi males than females. Lower incisor to A$\operatorname{Pog}(\mathrm{L} 1$ to A-Pog) and lower lip to E plane was significantly longer $(\mathrm{p}<0.05)$ in Saudi males than females. Other measurements had no significant difference between Saudi males and females. Conclusion: The craniofacial morphology of the Saudi males was different from Saudi females using Ricketts analysis. This study will help the clinicians to diagnosis and treatment planning of orthodontic and orthognathic patients.

Keywords: Diagnostic Techniques and Procedures; Orthodontics; Radiography; Cephalometry.
\end{abstract}




\section{Introduction}

There are many physical differences between the races of different geographic areas of the world. Some are strongly inherited, and some are influenced by nutrition, social lifestyle and environment, such as the size and shape of the body [1]. With increased social communication, social media, socio-economic condition and personal interest, people now increasingly become a focus on the face and the jaws. The cephalometric (Ceph) norms and analysis of each ethnic group were established to outline the skeletal characteristics of a "good occlusion" and "good face" [2]. The craniofacial area especially faces, which undergoes major changes from ethnic to ethnic groups. For different ethnic and racial groups, Ceph standards values were gradually established and found that there was no universal Ceph standard value. Ceph norms vary from ethnic to ethnic groups. Ceph analysis is an essential part of the diagnosis and treatment planning of orthodontic treatment. A clinical Ceph analysis can define a normal face in a population. Ceph standard values are a well-accepted practical guideline in orthodontic for diagnosis and treatment planning [3].

The lateral Ceph radiograph is a two-dimensional radiograph, which is often used in orthodontics treatment for diagnosis, treatment planning of malocclusion, the prognosis of the treatment, post-treatment evaluation, growth pattern in the craniofacial complex, pathology of craniofacial structures [4] and research purpose. The purpose of Ceph radiography was to assess the relationships of the teeth to their supporting bone and vertical and horizontal relation of a jaw to a cranial base [5]. Several studies have been carried out to determine the craniofacial norms of different populations in the Arabic-speaking countries [6-13]. For Saudis, several studies were developed using different Ceph analysis [14-20]. According to these researchers, the Saudi population was found to have distinct craniofacial features as compared with other populations and due to ethnic variation.

Rickett's analysis is one of the generally used Ceph analysis [21,22]. Ricketts proposed to use points, planes and axes with the traditional landmark [21] and used the esthetic plane, which was from the vermillion border of the lower lip to the E-line (soft tissue pogonion - nose tip). For young patients, he found that the measurement of the esthetic line was $0 \mathrm{~mm} \pm 3 \mathrm{~mm}[21,22]$.

There was no study has been conducted in the Saudi population using Rickett's analysis. Hence, the study was done to establish RA norms for the Saudi population.

\section{Material and Methods}

Study Design and Sample

In this cross-sectional study, Ceph radiographs of 500 subjects with class I occlusion (250 females and 250 males) were taken for each subject based on: the teeth in centric occlusion, no previous orthodontic treatment, sample ages range 18-30 years old, no skeletal or craniofacial abnormality, both parents and grandparents were Saudi.

Ricketts used the Ceph landmarks are presented in Table 1. Details analysis is presented in Figures 1 and 2 .

Table 1. Planes and angles used in RA.

\begin{tabular}{ll}
\hline \multicolumn{1}{c}{ Landmark } & \multicolumn{1}{c}{ Description } \\
\hline 1. Facial axis(Y-axis) & The angle between Ba-N and Pt-Gn lines. \\
2. Facial angle & The angle between the FH plane and N-Pog plane. \\
3. MD plane to FH & Angle between the mandibular plane and FH plane. \\
4. Facial taper & The angle between the mandibular plane and N-Pog line.
\end{tabular}


5. Lower facial height

6. Mandibular arc

7. Palatal plane to $\mathrm{FH}$

8. Maxillary convexity

9. $\mathrm{U}_{1}$ to $\mathrm{A} \mathrm{Pog}$

10. L1 to A Pog

11. L1 to A Pog angle

12. U6 to Ptv

13. U1-L1

14. Upper lip to E-plane

15. Lower lip to E-plane
The angle between ANS-Xi and Xi-Pm.

The angle between the condylar axis and corpus axis.

The angle between the Palatal plane and $\mathrm{FH}$ plane.

Distance from point A to N-Pog line.

Distance from the incisal edge of the upper central incisor to A-Pog line.

Distance from the incisal edge of the lower central incisor to A-Pog line.

The angle between the long axis of lower central incisor and A-Pog line.

Distance from the pterygoid vertical to the distal of the upper molar.

The interincisal angle between the long axis of upper and lower central incisors.

Distance from upper lip to E plane.

Distance from lower lip to $\mathrm{E}$ plane.

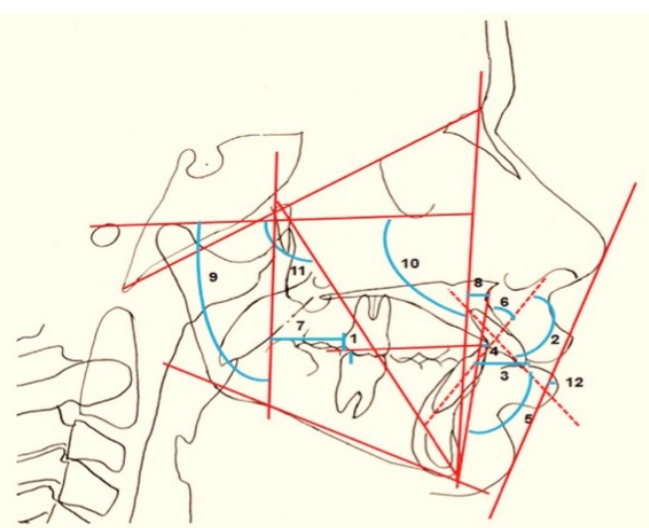

Twelve factors of the Ricketts Analysis

1-Molar relationship ( $\mathrm{mm}$ );

7- Position of the maxillary molar (mm);

2- Interincisive angle $\left({ }^{\circ}\right)$;

8- Maxillary convexity ( $\mathrm{mm}$ );

3- Protrusion of maxillaryincisor ( $\mathrm{mm}$ );

9- Angle of mandibular plane ( $\left.{ }^{\circ}\right)$;

4- Protrusion of mandibularincisor ( $\mathrm{mm}$ );

10-Facial depth $\left({ }^{\circ}\right)$;

5-Inclination of maxillaryincisor $\left({ }^{\circ}\right)$;

11- Facial axis angle $\left({ }^{\circ}\right)$;

6-Inclination of mandibularincisor $\left({ }^{\circ}\right)$;

12- Lower lip protrusion(mm).

Figure 1. Ricketts analysis (Cassos Sofware).

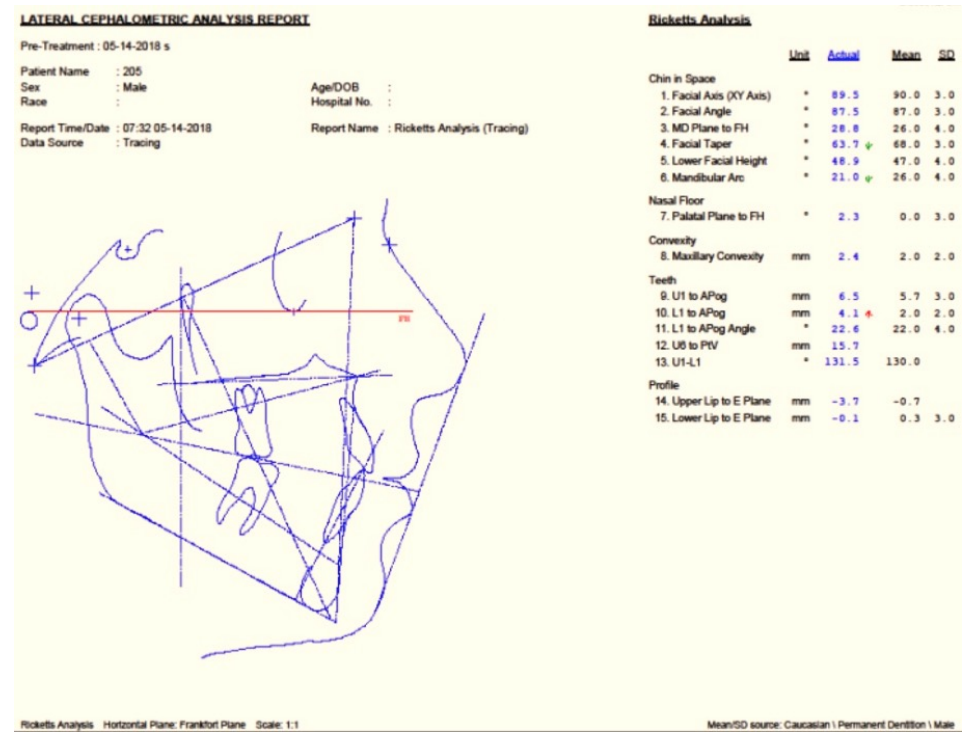

Figure 2. Ricketts analysis tracing (Cassos Software). 
Statistical Analysis

Statistical analysis was done by Statistical Package for the Social Sciences (SPSS) software, version 24 (IBM SPSS, Chicago, IL, USA). An independent t-test was used to test the level of significance between genders. The statistical significance level was set to $\alpha=0.05$ for all variables.

Ethical Aspects

Permission to use Ceph for the research purpose approval taken from the directorate of health affair in Hafer ALBatin, MOH, KSA. Ethical approval by Universiti Sains Malaysia (Protocol No. $\mathrm{USM} / \mathrm{JEPeM} / 17120719)$.

\section{Results}

Disparities of Ceph measurements of RA data of angular and linear measurements between Saudi male and female population were tabulated (Table 2). In this analysis, 3 variables showed significant differences at various levels out of 15 measurements. The result showed that the distal position of the maxillary first molar to pterygoid vertical plane (U6 to Ptv) measurement was highly significantly greater $(\mathrm{p}<0.001)$ in Saudi males than females. Lower incisor to A-Pog (L1 to A-Pog) and lower lip to E plane was significantly longer $(\mathrm{p}<0.05)$ in Saudi males than females. Other measurements had no significant difference between Saudi males and females.

Table 2. Descriptive statistical comparison of Ceph measurements between Saudi males and females using RA.

\begin{tabular}{|c|c|c|c|c|c|c|c|}
\hline \multirow{2}{*}{ Variables } & \multirow[t]{2}{*}{ Gender } & \multirow[t]{2}{*}{ Mean } & \multirow[t]{2}{*}{ SD } & \multirow[t]{2}{*}{ SE } & \multicolumn{2}{|c|}{$95 \%$ CI } & \multirow[t]{2}{*}{ p-value } \\
\hline & & & & & Lower & Upper & \\
\hline \multirow[t]{2}{*}{ Facial axis $\left(^{0}\right)$} & Male & 87.433 & 5.651 & 0.356 & -0.478 & 1.366 & \multirow{2}{*}{0.344} \\
\hline & Female & 86.988 & 5.003 & 0.308 & -0.480 & 1.369 & \\
\hline \multirow[t]{2}{*}{ Facial Angle $\left({ }^{\circ}\right)$} & Male & 85.792 & 4.257 & 0.268 & -0.643 & 0.832 & \multirow{2}{*}{0.802} \\
\hline & Female & 85.698 & 4.265 & 0.263 & -0.643 & 0.832 & \\
\hline \multirow[t]{2}{*}{ MD Plane to $\mathrm{FH}\left(^{\circ}\right)$} & Male & 28.718 & 7.136 & 0.450 & -1.344 & 1.133 & \multirow{2}{*}{0.867} \\
\hline & Female & 28.823 & 7.181 & 0.442 & -1.344 & 1.133 & \\
\hline \multirow[t]{2}{*}{ Facial Taper $\left(^{0}\right)$} & Male & 65.485 & 5.039 & 0.317 & -0.869 & 0.876 & \multirow{2}{*}{0.993} \\
\hline & Female & 65.481 & 5.048 & 0.311 & -0.869 & 0.876 & \\
\hline \multirow[t]{2}{*}{ Lower Facial Height $\left(^{\circ}\right)$} & Male & 45.712 & 5.125 & 0.323 & -0.517 & 1.256 & \multirow{2}{*}{0.413} \\
\hline & Female & 45.343 & 5.127 & 0.316 & -0.517 & 1.256 & \\
\hline \multirow[t]{2}{*}{ Mandibular Arc $\left(^{0}\right)$} & Male & 26.309 & 9.240 & 0.582 & -0.640 & 2.636 & \multirow{2}{*}{0.232} \\
\hline & Female & 25.311 & 9.682 & 0.596 & -0.639 & 2.634 & \\
\hline \multirow[t]{2}{*}{ Palatal Plane to $\mathrm{FH}\left(^{0}\right)$} & Male & -0.832 & 4.163 & 0.262 & -0.206 & 1.311 & \multirow{2}{*}{0.153} \\
\hline & Female & -1.385 & 4.584 & 0.282 & -0.204 & 1.309 & \\
\hline \multirow[t]{2}{*}{ Maxillary Convexity (mm) } & Male & 3.366 & 3.599 & 0.227 & -0.703 & 0.415 & \multirow{2}{*}{0.613} \\
\hline & Female & 3.510 & 2.838 & 0.175 & -0.706 & 0.418 & \\
\hline \multirow[t]{2}{*}{ U1 To A Pog (mm) } & Male & 8.405 & 3.049 & 0.192 & -0.242 & 0.743 & \multirow{2}{*}{0.319} \\
\hline & Female & 8.155 & 2.637 & 0.162 & -0.244 & 0.744 & \\
\hline \multirow[t]{2}{*}{ L1 To A Pog (mm) } & Male & 4.708 & 3.224 & 0.203 & 0.048 & 1.049 & \multirow{2}{*}{$0.032^{*}$} \\
\hline & Female & 4.160 & 2.535 & 0.156 & 0.045 & 1.052 & \\
\hline \multirow[t]{2}{*}{ L1 To A Pog Angle $\left(^{0}\right)$} & Male & 27.015 & 12.445 & 0.784 & -2.513 & 1.803 & \multirow{2}{*}{0.747} \\
\hline & Female & 27.370 & 12.494 & 0.769 & -2.512 & 1.802 & \\
\hline \multirow[t]{2}{*}{ U6 to Ptv (mm) } & Male & 17.658 & 5.271 & 0.332 & 1.146 & 2.863 & \multirow{2}{*}{$<0.001^{*}$} \\
\hline & Female & 15.653 & 4.649 & 0.286 & 1.143 & 2.866 & \\
\hline $\mathrm{U}_{1}-\mathrm{L}_{1}\left({ }^{0}\right)$ & Male & 116.402 & 10.715 & 0.675 & -0.623 & 2.861 & 0907 \\
\hline & Female & 115.283 & 9.408 & 0.579 & -0.628 & 2.867 & 0.201 \\
\hline
\end{tabular}




\begin{tabular}{llcccccc} 
Upper Lip to E Plane (mm) & Male & -2.024 & 3.584 & 0.226 & -0.575 & 0.533 & 0.940 \\
& Female & -2.003 & 2.788 & 0.172 & -0.578 & 0.536 & \\
Lower Lip to E Plane $(\mathrm{mm})$ & Male & 2.516 & 4.043 & 0.255 & 0.059 & 1.293 & $0.032^{*}$ \\
& Female & 1.840 & 3.040 & 0.187 & 0.055 & 1.297 & \\
\hline
\end{tabular}

$\overline{\mathrm{SD}}=$ Standard Deviation; $\mathrm{SE}=$ Standard Error; $\mathrm{CI}=$ Confidence Interval; $*$ Statistically significant.

\section{Discussion}

Different races and ethnic groups have different types of dental and facial pattern and these differences make Ceph norms specific to a particular ethnic group [23]. Ricketts Ceph analysis is one of the most important analyses. It serves as a major role in prognosis and early detection of craniofacial anomalies. Ricketts established data of variables is helpful in determining the vertical, transverse, skeletal and dental problems [22] and emphasized the growth and facial pattern. RA has 5 components, and these are - Dental relations, Skeletal relations, Dental to skeletal relation, Jaw to cranium and Internal structures. According to RA, for orthodontic patients, there are three types of facial patterns: (i) brachyo facial pattern (short face), (ii) mesio facial pattern (medium face) and (iii) dolico facial pattern (long face) [24].

In this analysis, Lower incisor was proclined in Saudi males than females which are measured by L1 to A Pog. This indicated lower jaw proclination for Saudi males than females. It has been shown that mandibular incisors were more proclined in Iraqi people [25]. Mandibular incisor also more proclination in Anatolian Turkish adults [26]. Saudi males have protruded maxillary first permanent molar than females, which is measured by U6 to Ptv, and it was $17.658 \mathrm{~mm}$ for Saudi males. That was the chance of impaction in the upper jaw. The lower lip was more protruded in Saudi males in comparison to females, which is measured by lower lip to E plane.

Almost all measurements of Saudi adult males were larger than the Ricketts mean values data $[27,28]$. These differences may be due to only male data were analyzed for the Saudi population. Previous study found that the upper and lower lips of the Japanese were anteriorly positioned in all analyses [29]. The lower lip was retrusive when compared to the $\mathrm{E}$ line between males and females for Malaysian Indian [30]. Saudis are a nation with various regional ethnic groups in the Arabian Peninsula. Saudi Arabians are considered Caucasians subgroup. They show different characteristics of features of Caucasian. Previous study demonstrated that have a tendency of bimaxillary protrusion and less lower facial height [18].

Indians have less prognathic mandible and maxilla with less protrusive upper and lower incisors and lips in comparison to the Chinese and Malays [31]. The Iranian had a convex facial profile and bimaxillary dental protrusion [32].

\section{Conclusion}

The purpose of this study is to identify Ricketts Ceph norms or standards value for the Saudi population. Saudi males and females had some significant differences in Ceph measurement. Saudi males had large craniofacial morphology measurements than females. The established norms can be used as a reference in the orthodontic and orthognathic treatment of Saudi adults.

\section{Authors' Contributions}

$\begin{array}{ccl}\text { AS } \quad \text { (D) 0000-0002-9203-6910 } & \begin{array}{l}\text { Conceptualization, Methodology, Investigation, Formal Analysis, Writing - } \\ \text { Original Draft Preparation and Writing-Review and Editing. } \\ \text { Conceptualization, Methodology, Investigation, Formal Analysis, Writing - } \\ \text { Original Draft Preparation and Writing - Review and Editing. }\end{array} \quad \text { (D) 0000-0001-9216-4026 }\end{array}$


MKA (D) 0000-0001-7131-1752 Conceptualization, Methodology, Investigation, Formal Analysis, Writing Original Draft Preparation and Writing - Review and Editing.

All authors declare that they contributed to critical review of intellectual content and approval of the final version to be published.

\section{Financial Support}

None.

\section{Conflict of Interest}

The authors declare no conflicts of interest.

\section{References}

[1] American Association of Physical Anthropologists. AAPA Statement on Biological Aspects of Race. Am J Phys Anthropol 1996; 101(4):569-70. https://doi.org/10.1002/ajpa.1331010408

[2] Gleis R, Brezninak N, Lieberman M. Israeli cephalometric standards compared to downs and Steinner analysis. Angle Orthod 1990; 60(1):35-41.

[3] Moyers RE, Bookstein F, Hunter W. Analysis of the Craniofacial Skeleton: Cephalometrics. In: Moyers RE. Handbook of Orthodontics. 4th ed. Chicago: Yearbook Medical Publishers; 1988. p. 247-309

[4] Bishara SE, Fernandez AG. Cephalometric comparisons of the dentofacial relationships of two adolescent. Populations from lowa and northern Mexico. Am J Orthod 1985; 10:314-22.

https://doi.org/10.1016/0002-9416(85)90131-9

[5] Profit WR. Contemporary Orthodontics. St Louis: C.V. Mosby Company; 1986. pp. 148-150.

[6] Hamdan AM, Rock WP. Cephalometric norms in an Arabic population. J Orthod 200 1; 28(4):297-300. https://doi.org/10.1093/ortho/28.4.297

[7] Al-Gunaid T, Yamada K, Yamaki M, Saito I. Soft-tissue cephalometric norms in Yemeni men. Am J Orthod Dentofacial Orthop 2007; 132(5):576.e7-14. https://doi.org/10.1016/j.ajodo.2007.03.018

[8] Al-Azemi R, Al-Jame B, Artun J. Lateral cephalometric norms for adolescent Kuwaitis: soft tissue measurements. Med Princ Pract 2008; 17(3):215-20. https://doi.org/10.1159/000117795

[9] Hamdan AM. Soft tissue morphology of Jordanian adolescents. Angle Orthod 2010; 80(1):80-5. https://doi.org/10.2319/010809-17.1

[10] Aldrees AM. Lateral cephalometric norms for Saudi adults: a meta-analysis. Saudi Dent J 2011; 23(1):3-7. https://doi.org/10.1016/j.sdentj.2010.09.002

[11] Abu-Tayyem HM, Alshamsi AH, Hafez S, Eldin EM. Cephalometric norms for a sample of Emirates adults. Open J Stomatol 2011; 1:75-83. https://doi.org/10.4236/ojst.2011.13013

[12] Al-Azemi R, Årtun J. Posteroanterior cephalometric norms for an adolescent Kuwaiti population. Eur J Orthod 2012; 34(3):312-7. https://doi.org/10.1093/ejo/cjroo7

[13] Al Zain T, Ferguson DJ. Cephalometric characterization of an adult Emirati sample with Class I malocclusion. J Orthod Sci 2012; 1(1):11-5. https://doi.org/10.4103/2278-0203.94772

[14] Shalhoub SY, Sarhan OA, Shaikh HS. Adult cephalometric norms for Saudi Arabian with comparison of values for Saudi and North American Caucasian. Br J Orthod 1987; 14(4):273-9. https://doi.org/10.1179/bjo.14.4.273

[15] Sarhan OA, Nashashibi IA. A comparative study between two randomly selected samples from which to derive standards for craniofacial measurements. J Oral Rehabil 1988; 15(3):251-5. https://doi.org/10.1111/j.1365-2842.1988.tbo0154.x

[16] Al-Barakati S. Skeleto-dental characteristic features among Saudi female school children. A cephalometric study. [Thesis]. College of Dentistry: King Saud University, 1996.

[17] Al-Barakati SF. The wits appraisal in a Saudi population sample. Saudi Dent J 2002; 14(4):89-92.

[18] Al Jasser NM. Cephalometric evaluation of craniofacial variation in normal Saudi population according to Steiner analysis. Saudi Med J 2000; $21(8): 746-50$.

[19] Al Jasser NM. Cephalometric evalution for Saudi population using the Downs and Steiner analysis. J Contemp Dent Pract 2005; 6(2):52-63.

[20] Hassan AH. Cephalometric norms for Saudi adults living in the Western Region of Saudi Arabia. Angle Orthod 2006; 76(1):109-13.

[21] Rickett's RM. Cephalometric analysis and synthesis. Angle Orthod 1961; 31(3):141-56.

[22] Rickett's RM. Cephalometric synthesis. Am J Orthod 1960; 46(9):647-73.

[23] Alam MK, Basri R, Purmal K, Sikder MA, Saifuddin M, Iida J. Determining cephalometric norms for Bangladeshi adult using Bjork-Jarabaks' analysis. Int Med J 2012; 19(4):329-32. 
[24] Ricketts R, Bench R, Gugino C, Hilgers J, Schulhof R. Bioprogressive Therapy. Denver: Rocky Mountain Orthodontics; 1979. 367pp.

[25] Al-Khannaq MR. Cephalometric description of class II sample ages 11-14 years across sectional growth. [Thesis]. College of Dentistry: Baghdad University; 1993.

[26] Basciftci FA, Uysal T, Buyukerkmen A. Craniofacial structure of Anatolian Turkish adults with normal occlusions and wellbalanced faces. Am J Orthod Dentofacial Orthop 2004; 125(3):366-72. https://doi.org/10.1016/j.ajodo.2003.04.004

[27] Kundi IU, Kumar H, Baig MN, Alam MK, Alashraray YAM, Al-Sharari EMS. Posterior anterior (pa) cephalometric assessment for Saudi adult male population. Pak Oral Dent J 2018; 38(4):457-62.

[28] Ricketts RM, Bench RW, Hilgers JJ. Schulhof R. An overview of computerized cephalometric. Am J Orthod 1972; 61(1):1-28. https://doi.org/10.1016/0002-9416(72)90172-8

[29] Alcalde RE, Jinno T, Orsini MG, Sasaki A, Sugiyama RM, Matsumura T. Soft tissue cephalometric norms in Japanese adults. Am J Orthod Dentofac Orthop 2000; 118(1):84-9. https://doi.org/10.1067/mod.2000.104411

[30] Purmal K, Alam MK, Zam Zam NM. Cephalometric norms of Malaysian adult Indian. Int Med J 2013; 20(2):192-6.

[31] Lew KK. Cephalometric ideals in Chinese, Malay and Indian ethnic groups. Asian J Aesthet Dent 1994; 2(1):35-8.

[32] Hajighadimi M, Doughrety HL, Garakani F. Cephalometric evaluation of Iranian children. Am J Orthod 1981; 79(2):192-7. https://doi.org/10.1016/0002-9416(81)90317-1 